\title{
PENGARUH BERAT LELE DUMBO (Clarias gariepinus) TERHADAP RENDEMEN ABON IKAN LELE DUMBO SERTA PENDUGAAN MASA SIMPAN DAN MASA KEDALUWARSA ABON IKAN LELE DUMBO \\ Oleh
}

\author{
Randi B.S Salampessy ${ }^{1}$, Tb. Haeru R ${ }^{1}$, Erni Marlina ${ }^{1}$, Eko Novi S ${ }^{2}$ \\ Dosen Sekolah Tinggi Perikanan ${ }^{1}$, Taruna Sekolah Tinggi Perikanan ${ }^{2}$
}

\begin{abstract}
Abstrak
Produksi ikan lele di Indonesia dari tahun ke tahun meningkat tinggi. Kenaikan produksi ikan lele sangat tinggi dengan jumlah rata-rata pada tahun 2007-2011 sebesar 39,82 persen, produksi ikan lele melonjak dari 242.811 ton pada tahun 2010 menjadi 340.674 ton pada tahun 2011 atau naik sebesar 40,30 persen. Kenaikan total produksi nasional dipengaruhi oleh naiknya produksi ikan lele di setiap provinsi (Ditjenkan P2HP, 2011).

Tujuan dari penelitian ini adalah untuk mengetahui proses pengolahan abon ikan lele, mutu bahan baku dan produk akhir, rendemen abon ikan lele dari ukuran yang berbeda, masa umur simpan dan masa kedaluwarsa abon ikan lele dumbo. Faktor - faktor yang diluar objek penelitian yang diteliti diatur sehingga semuanya homogen. Penelitian yang dilakukan dibagi menjadi 2 (dua) yaitu penelitian pendahuluan dan penelitian lanjutan. Pada penelitian pendahulan meliputi pengolahan abon, mutu bahan baku dan produk serta perhitungan rendemen. Variabel yang digunakan dalam menentukan perbedaan rendemen adalah ukuran (size), yang dibedakan menjadi 3 (tiga) yaitu lele ukuran (size) 3 ekor $/ \mathrm{kg}, 4$ ekor $/ \mathrm{kg}$, dan 5 ekor/kg, kemudian pada penelitian lanjutan yang dilakukan adalah menentukan umur simpan dan masa kedaluwarsa abon ikan lele dumbo. Analisa data yang dilakukan dengan menggunakan RAL faktorial. Penentuan umur simpan dapat ditentukan dengan rumus $\mathrm{Ts}=\mathrm{Ts}_{1} \cdot \mathrm{Q} 10^{\wedge^{\mathrm{T} / 10}}$.

Hasil dari pengujian mikrobiologi untuk bahan baku ALT adalah $5 \times 10^{5} \mathrm{kol} / \mathrm{gr}$, sedangkan pengujian mikrobiologi pada produk abon adalah 5,0x $10^{4} \mathrm{kol} / \mathrm{gr}$ dan uji $E$. Coli yaitu $<3$ APM. Hasil uji kimia air dan protein maks $15 \%$ dan protein $\min 30 \%$. Perhitungan rendemen akhir abon pada ukuran (size) 3 ekor $/ \mathrm{kg} 25,92 \%, 4$ ekor $/ \mathrm{kg}$ $27,53 \%$, dan 5 ekor $/ \mathrm{kg} 28,88 \%$. Hasil analisa menunjukkan ada pengaruh yang signifikan antara berat lele dumbo (Clarias gariepinus) terhadap rendemen abon ikan lele dumbo. Jika abon ikan lele disimpan pada suhu chilling $5^{\circ} \mathrm{C}$, maka umur simpan abon ikan lele menjadi 28,2 bulan pada suhu $5^{\circ} \mathrm{C}$ atau dari tanggal 30 April $2013 \mathrm{~s} / \mathrm{d}$ 2 september 2015 sehingga masa kedaluwarsa nya adalah 2 September 2015.
\end{abstract}

Keywords : Clarias gariepinus, abon ikan lele

\section{PENDAHULUAN}

\section{Latar belakang}

Perkembangan produksi ikan lele

di Indonesia dari tahun ke tahun meningkat tinggi. Kenaikan produksi ikan lele sangat tinggi dengan jumlah rata-rata pada tahun 2007-2011 sebesar 39,82 persen, produksi ikan lele melonjak dari 242.811 ton pada tahun 2010 menjadi 340.674 ton pada tahun 2011 atau naik sebesar 40,30 persen. 
Kenaikan total produksi nasional dipengaruhi oleh naiknya produksi ikan lele di setiap provinsi (Ditjenkan P2HP, 2011).

Abon merupakan olahan dari ikan lele yang memiliki nilai tambah dan baik kandungan gizi nya. Praktek akhir ini ikan lele yang digunakan diambil dari ukuran (size) tertentu ini dikarenakan dari beberapa ukuran tertentu tersebut, memiliki jumlah rendemen yang berbeda, dan juga diversifikasi produk dari ikan lele ini menjadi penting untuk diketahui masa umur simpan nya. Awal ketika diproduksi, mutu produk dianggap dalam keadaan $100 \%$, dan akan menurun sejalan dengan lamanya penyimpanan atau distribusi.

Tujuan dari penelitian ini adalah mengetahui cara pengolahan abon ikan lele dumbo, mutu bahan baku dan produk akhir, rendemen abon ikan lele dumbo dari ukuran yang berbeda serta masa umur simpan abon ikan lele dumbo.

\section{METODE PENELITIAN \\ Waktu dan Tempat}

Penelitian ini dilaksanakan mulai dari tanggal 15 February sampai $15 \mathrm{Mei}$ 2013, di workshop pengolahan, Laboratorium Mikrobiologi dan Laboratorium Kimia Sekolah Tinggi Perikanan.

\section{Alat dan Bahan}

Alat

Alat yang digunakan antara lain: kompor, blender, penumbuk, alat pengepres (spinner), baskom, timbangan, pisau, spatula, talenan, dan dandang, untuk pengujian kimia oven, desikator, cawan porselin, penjepit, timbangan, tanur, alat destilasi, alat kyedhal dan spectrofotometri, sedangkan untuk pengujian mikrobiologi antara lain: petridish, pipet, botol pengencer, bunsen, incubator, oven, tabung reaksi, dan coloni counter.

Bahan
Bahan yang digunakan adalah ikan lele dumbo dalam kondisi hidup dengan ukuran 3 ekor/kg dengan kisaran antara $330 \mathrm{gr}$ s/d 335 gr/ekor, 4 ekor/kg dengan kisaran antara 250 gr s/d 255 gr, 5 ekor/kg dengan kisaran berat $200 \mathrm{gr}$ s/d 205 gr, bawang putih, bawang merah, gula, kemiri, cabai merah, minyak goreng, sereh, daun jeruk, daun salam, jinten, ketumbar, kunyit dan lengkuas. $\mathrm{H}_{2} \mathrm{SO}_{4}, \mathrm{HCl}, \mathrm{CuSO}_{4}, \mathrm{~K}_{2} \mathrm{SO}_{4}, \mathrm{NaOH}$, Natrium hidroksidathiosulfat, $\mathrm{HCl}$ dan TBA.

\section{Metode Penelitian}

Penelitian dibagi menjadi dua tahap, tahap pertama yaitu penelitian pendahuluan dan dilanjutkan dengan penelitian lanjutan tahap kedua.

\section{Penelitian pendahuluan}

Penelitian pendahuluan terdiri dari 2 tahap yaitu : tahap 1 pengolahan abon dengan ukuran masing masing 3 ekor/kg, 4 ekor/kg, dan 5 ekor/kg. Untuk mempermudah dalam penyebutan ukuran (size) menggunakan notasi dengan A ukuran (size) 3 ekor $/ \mathrm{kg}, \mathrm{B}$ ukuran (size) 4 ekor/kg dan $\mathrm{C}$ ukuran (size) 5 ekor $/ \mathrm{kg}$.

Proses abon lele dimulai dari penerimaan bahan baku, penimbangan dan sortasi, penyiangan, pencucian, pengukusan (pre- cooking), pengambilan daging (pencabikan), pengepresan, pencampuran, pemasakan, penirisan minyak, penguraian, penimbangan dan pengemasan.

Tahap ke-2 melakukan perhitungan rendemen yang diawali dari menghitung berat awal ikan lele hingga pada saat menjadi abon ikan lele. Perhitungan rendemen dilakukan sebanyak 3 kali ulangan pada masing masing ukuran (size).

\section{Pengujian Kimia dan Mikrobiologi}

Melakukan uji kimia (air dan protein) pada abon dan pengujian mikrobiologi yang terdiri dari pengujian (ALT) pada bahan baku dan pengujian (E. Coli, $A L T)$ pada abon, pengujian dilakukan sebanyak 3 kali ulangan pada masing - 
masing ukuran (size). Metode pengujian kimia Uji Kadar Air (SNI 01-2354.22006), dan Protein (SNI 01-2354.42006), dan Metode Pengujian Mikrobiologi ALT (SNI 01-2354-2006) dan E. Coli (SNI 01-2332-2006).

\section{Perhitungan Rendemen Abon Ikan}

Menghitung berat awal ikan dilakukan dengan melakukan penimbangan dengan timbangan digital. Kemudian menghitung rendemen akhir dengan rumus sebagai berikut :

$$
\text { Rendemen } \frac{\text { Beral abon }}{\text { Berat awal }} \times 100 \%
$$

\section{Penelitian Lanjutan}

Penelitian lanjutan yang dilakukan untuk mengetahui umur simpan abon lele yang telah diketahui rendemen dari masing - masing ukuran (size) dan perubahan kimiawi pada abon, kemudian dilakukan uji TBA (Thiobarbiturat acid) dengan 2 kali ulangan, uji TBA dilakukan karena ikatan lemak yang paling akhir (malonaldehide) merupakan ikatan yang pertama dapat dilihat tingkat kerusakan nya (Syarief dan Halid, 1991).

Tahap ulangan pertama menentukan berapa hari yang digunakan dalam penentuan daya awet dilakukan dengan percobaan (Trial and eror) sebanyak 10 hari dari mulai tanggal 17 September 2013 s/d 26 September 2014 dengan uji TBA pada suhu ruang yaitu $25{ }^{\circ} \mathrm{C}$ s/d $27^{\circ} \mathrm{C}$ dan hasil uji TBA dilakukan perbandingan dengan uji organoleptik dengan parameter bau.

Jarak atau (range) hari (waktu pengujian) telah ditentukan melalui percobaan (Trial and eror), dilanjutkan dengan tahap ulangan kedua dengan melakukan uji TBA setiap 2 hari sekali pada masing - masing ukuran (size) abon lele pada suhu $25^{\circ} \mathrm{C}, 35^{\circ} \mathrm{C}$ dan, $45^{\circ} \mathrm{C}$, dalam menentukan perbedaan suhu untuk penempatan sampel perbedaan suhu min $3^{\circ} \mathrm{C}$ dan maks $10^{\circ} \mathrm{C}$, karena dengan perbedaan (range) suhu sekian proses kerusakan lemak (malonaldehide) dapat dilihat dengan Uji TBA. Uji TBA yang dilakukan setiap 2 hari sekali dari mulai tanggal dan hari Sabtu, 28 September 2013 s/d hari Minggu, 6 Oktober 2013 pada masing - masing ukuran (size), selanjutnya mencari persamaan dengan cara menggunakan regresi, setelah itu menggunakan Model Arhenius untuk menduga berapa besar laju penurunan mutu, dan dengan Model $\mathrm{Q}_{10}$ untuk menentukan masa kadaluwarsa pada hari dan suhu yang berbeda.

\section{Metode Analisis Data}

Analisa yang digunakan untuk menyajikan data mengenai pengaruh berat lele dumbo (Clarias gariepinus) terhadap rendemen abon ikan lele dumbo, disajikan dengan menggunakan rancangan percobaan yaitu Rancangan Acak Lengkap Faktorial, karena pada penelitian kali ini hanya menggunakan satu faktor pembeda yaitu ukuran (size) dan sampel yang digunakan adalah ikan lele yang kondisi dan sumbernya didapatkan dalam keadaan yang sama sehingga dapat dikatakan homogen.

\section{Deskriptif}

Deskriptif merupakan penyajian yang dilakukan dengan menjelaskan halhal yang diteliti selama penelitian sesuai dengan batasan masalah kemudian di analisa dan diolah yang selanjutnya dikaji dengan referensi yang ada sesuai dengan tujuan dan batasan masalah yang telah ditetapkan. Sekaligus melukiskan secara sistematis fakta tertentu dengan faktual dan cermat.

\section{Rancangan Acak Lengkap}

Vincent Gasperz (1991)

Model

$Y_{i j}=\mu+\tau_{i}+\beta_{i}+\varepsilon_{i j}$

Dimana :

$Y_{i j}=$ Rendemen abon lele ke- $\mathrm{j}$ yang memperoleh perlakuan $\mathrm{ke}-\mathrm{i}$

$\mu=$ Nilai tengah umum (rata - rata populasi) rendemen 
$\tau_{i}=$ Pengaruh perlakuan (Rendemen) ke- I

$\beta_{j}=$ Pengaruh size ikan ke $\mathrm{j}$

$\varepsilon_{i j}=$ Pengaruh galat percobaan pada abon lele ke- $\mathrm{j}$ yang memperoleh perlakuan ke- I

Data hasil analisa pada penelitian pendahuluan dilanjutkan dengan penelitian lanjutan untuk menduga berapa besar laju penurunan mutu dan untuk menentukan waktu kadaluwarsa pada hari dan suhu yang berbeda, yang dilakukan dengan cara mencari persamaan :

\section{REGRESI}

Vincent Gasperz (1991)

Rumus persamaan :

Di

$$
\begin{array}{lll}
\mathrm{y}=\mathrm{bx}+\mathrm{a} & \\
\mathrm{y} & : & \text { variabel tak bebas } \\
\mathrm{x} & : & \text { variabel bebas }
\end{array}
$$

Hasil perhitungan regresi kemudian didapatlah koefisien regresi nya (intershep), setelah itu dilanjutkan ke dalam Model Arhenius :

\section{MODEL ARRHENIUS} (1991).

Rizal syarief dan Hariyadi halid

Asumsi untuk penggunaan model Arrhenius ini :

a. Perubahan faktor mutu hanya ditentukan oleh satu macam reaksi saja.

b. Tidak terjadi faktor lain yang mengakibatkan perubahan mutu.

c. Proses perubahan mutu dianggap bukan merupakan akibat dari proses -proses yang terjadi sebelumnya.

d. Suhu selama penyimpanan tetap atau dianggap tetap.

Untuk menduga laju penurunan mutu menggunakan persamaan Arhenius :

Dimana :

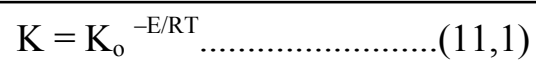

$\mathrm{K}$ : Konstanta penurunan mutu
$\mathrm{K}_{\mathrm{o}}$ : Konstanta (tidak tergantung pada suhu)

$\mathrm{E}$ : Energi aktivasi

$\mathrm{T}$ : Suhu mutlak $\left({ }^{\circ} \mathrm{C}+273 \mathrm{~K}\right)$

$\mathrm{R}$ : Konstanta gas $1.986 \mathrm{kal} / \mathrm{mol}$

Dan kemudian dilanjutkan dengan Model $\mathrm{Q}_{10}$ :

MODEL $\mathbf{Q}_{10}$ (1991).

Rizal Syarief dan Hariyadi Halid

$\mathrm{Q}_{10}$ adalah faktor percepatan reaksi dengan rumus :

$\mathrm{Q}_{10}=\underline{\text { Laju penurunan mutu pada suhu }(\mathrm{T}+10)}$......(11,3)

Laju penurunan mutu pada suhu $\mathrm{T}$

Di mana :

$\mathrm{T}$ : Suhu penyimpanan dalam ${ }^{\circ} \mathrm{C}$ Apabila perbedaan suhu penyimpanan (dT) tidak sama dengan 10 maka rumus berikut digunakan :

$\mathrm{Q}^{\mathrm{dt} / 10}=\frac{\mathrm{ts}\left(\mathrm{T}_{1}\right)}{\operatorname{Ts}\left(\mathrm{T}_{2}\right)}$

Di mana :

$\begin{aligned} \mathrm{T}^{\mathrm{T}} & \text { : suhu penyimpanan } \\ \mathrm{dalam}_{\mathrm{s}(\mathrm{T})} \mathrm{C} & \text { : masa kedaluwarsa jika }\end{aligned}$ disimpan pada suhu $\mathrm{T}$

ts $(\mathrm{T}+10) \quad$ : masa kedaluwarsa jika disimpan pada suhu $\mathrm{T}+10$

\section{Komparatif}

Komparatif merupakan analisa yang membandingkan hasil pengamatan secara langsung yang selanjutnya dikaitkan dengan literatur, narasumber ataupun dengan pengamatan lain yang serupa, apakah terdapat kesamaan dan perbedaan hasil pengamatan dengan bahan perbandingan tersebut.

\section{HASIL DAN PEMBAHASAN}

Penelitian Pendahuluan

Proses Penanganan dan Pengolahan Abon Ikan Lele Dumbo

Bahan baku berupa Lele Dumbo (Clarias gariepinus) dibeli dengan 
kondisi hidup, kemudian lele dilakukan pemberokan dilakukan selama 2 (dua) hari dan air kolam diganti setiap harinya.

\section{Penimbangan dan Sortasi}

Berat ikan lele dumbo dari masing - masing ukuran 3 ekor/kg berkisar antara $330 \mathrm{gr}$ s/d 335 gr/ekor, berat lele dumbo ukuran 4 ekor/kg berkisar antara 250 gr s/d 255 gr/ekor dan berat ikan lele dumbo 5 ekor $/ \mathrm{kg}$ berkisar antara $200 \mathrm{gr} \mathrm{s} / \mathrm{d} 205 \mathrm{gr} / \mathrm{ekor}$.

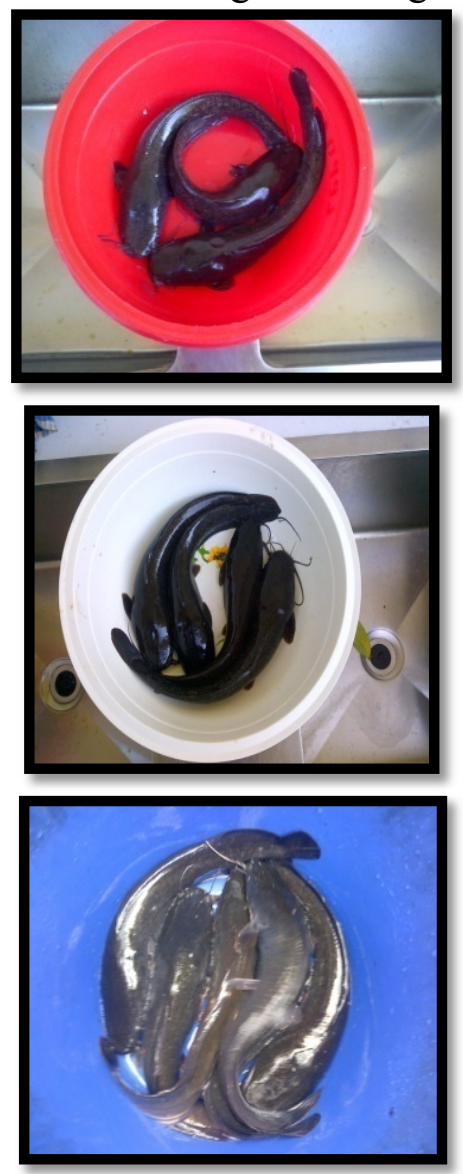

(A) 3 ekor $/ \mathrm{kg}$

4 ekor $/ \mathrm{kg} \quad$ (C) 5 ekor $/ \mathrm{kg}$

Gambar 1. Ikan lele dumbo berdasarkan berat dan ukuran (size)

Penyiangan

Perlakuan yang dilakukan untuk menghindari kontaminasi bakteri terhadap daging ikan (bahan baku) yang dilakukan adalah membuang isi perut dan kulit. Dapat dilihat pada Gambar 2.

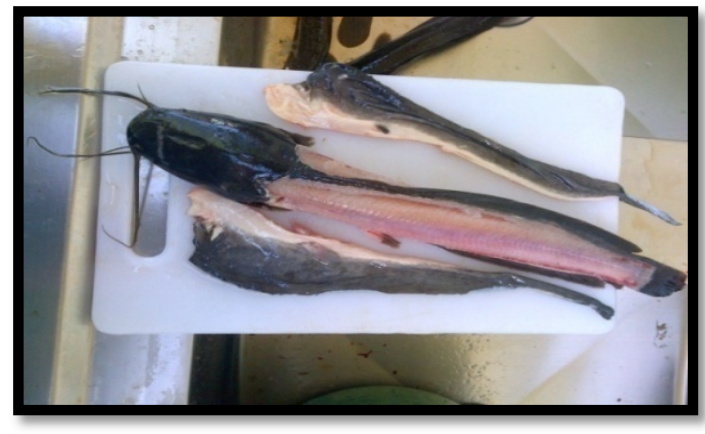

Gambar 2. Pembuangan kulit dan isi perut ikan lele dumbo

\section{Pencucian}

Proses pencucian ikan lele dumbo dilakukan dengan menggunakan air bersih dan mengalir suhu air berkisar antara $25^{\circ} \mathrm{C} \mathrm{s} / \mathrm{d} 27^{\circ} \mathrm{C}$. Pencucian adalah proses membersihkan melalui air bersih agar ikan bebas dari bahan yang memberatkan secara higienis. Tujuannya adalah untuk membersihkan dan mengenyahkan lendir, bakteri permukaan, darah, kotoran, dll (Ilyas, 1993).

\section{Pengukusan (pree-cooking)}

Proses pengukusan, ikan dikukus pada suhu $90^{\circ} \mathrm{C}$ s $/ \mathrm{d} 98,9{ }^{\circ} \mathrm{C}$ dalam waktu 30 menit kemudian ditambahkan daun salam dan sereh yang berfungsi untuk menghilangkan bau lumpur ikan lele. Pada proses pengukusan, ukuran ikan mengecil atau mengalami pengerutan, dan ikan berubah bentuk menjadi menggumpal. Ini disebabkan terjadinya proses modifikasi struktur sekunder, tersier, dan kuatener terhadap molekul protein dan kandungan air pada ikan menjadi keluar, sehingga struktur jaringan pada daging ikan menjadi kompak dan perubahan warna daging menjadi warna putih kekuningan.

Pemanasan dapat mempengaruhi daya ikat air. Semakin tinggi suhu maka jumlah air yang terikat semakin menurun. Sedangkan pada lemak, terjadi reaksi hidrolisis lemak. Penggunaan suhu tinggi menghasilkan energi yang terlalu tinggi, yang dapat memecah struktur lemak (Kusnandar, 2010). 


\section{Pencabikan}

Setelah pengukusan, tahapan selanjutnya adalah pencabikan untuk memisahkan antara tulang ikan dengan dagingnya. Hal ini sangat penting karena dibutuhkan ketelitian dalam pemisahan antara daging ikan dengan tulangnya, apabila pada daging ikan tersebut masih terdapat tulang - tulang ikan akan menimbulkan efek negatif apabila dikonsumsi setelah menjadi abon.

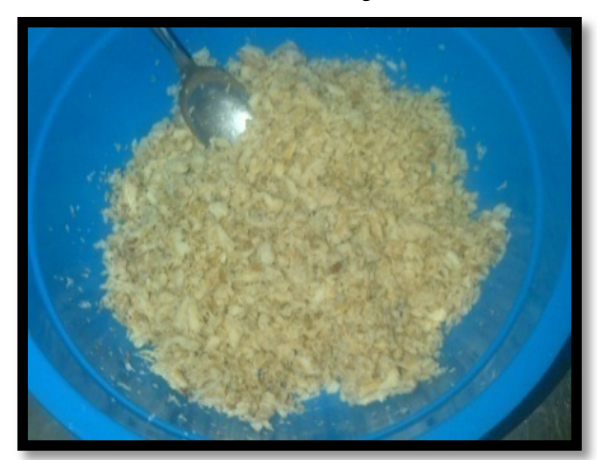

Gambar 3. Daging Ikan lele setelah dicabik

\section{Pengepresan I}

Daging ikan lele yang telah dicabik kemudian di masukkan ke dalam mesin pengepres (spiener), hal ini sangat berguna untuk mengurangi kadar air yang masih terdapat dalam daging ikan. Daging ikan lele di pres selama $15 \mathrm{~s} / \mathrm{d}$ 20 menit sampai daging ikan tidak menggumpal lagi.

\section{Pencampuran}

Bumbu

ditumis sampai menghasilkan aroma yang harum, hal ini dikarenakan senyawa- senyawa aromatik yang terkandung didalam bumbu - bumbu, lalu daging ikan yang telah dicabik dimasukkan dan dimasak hingga bumbu meresap ke dalam daging ikan dalam waktu 20 menit s/d 30 menit dengan suhu penggorengan $135^{\circ} \mathrm{C}$ s/d $145^{\circ} \mathrm{C}$.

\section{Pemasakan}

Tahap pemasakan, minyak harus dipanaskan terlebih dahulu sampai suhunya mencapai $180^{\circ} \mathrm{C}$. Daging ikan yang sudah dicampur dengan bumbu atau bahan lainnya digoreng dengan waktu 30 menit s/d 45 menit sesuai spesifikasi, dan dilakukan pengadukan secara terus menerus sampai berwarna spesifik abon ikan secara cermat dan saniter. Keuntungan yang dapat di peroleh dari proses penggorengan adalah perubahan tekstur. Produk yang digoreng mempunyai tekstur tertentu sesuai yang di inginkan ( Estiasih dan Ahmadi, 2011).

Proses penggorengan \pm 30 menit, tergantung dari banyaknya daging ikan yang akan digoreng. Pada tahap ini terjadi perubahan warna pada daging ikan menjadi warna coklat karena, terjadinya reaksi Maillard. Reaksi Maillard adalah reaksi-reaksi antara karbohidrat, khususnya gula pereduksi dengan gugus amina primer (Winarno, 2008).

\section{Penirisan minyak}

Abon ikan yang sudah matang dimasukkan kedalam alat pengurangan minyak (Pengepresan II) secara cepat, cermat dan saniter, yang bertujuan untuk memisahkan daging ikan dengan minyak yang digunakan untuk menggoreng. Sehingga didapatkan abon ikan yang dalam tekstur yang kering karena minyak sudah di pisahkan dengan abon.

Pengepresan bertujuan agar tidak terjadinya bau tengik pada abon/ sesuai dengan spesifikasi (SNI 7690.3:2013), karena tingginya kadar lemak pada abon yang berasal dari minyak. Proses pengepresan II dilakukan dalam waktu 20 s/d 30 menit sampai daging ikan lele benar - benar kering dan kandungan minyak nya sangat - sangat minim pada daging ikan lele tersebut.

\section{Penguraian}

Daging ikan lele yang telah dilakukan proses penggorengan dan pengepresan II telah dapat dikatakan sebagai abon ikan lele dumbo, akan tetapi abon ikan lele dumbo tersebut masih menggumpal sehingga proses penguraian sangat perlu dilakukan, karena hal ini sangat mempengaruhi tekstur yang akan didapat . 


\section{Penimbangan}

Proses penimbangan dilakukan untuk mengetahui berat abon yang didapatkan, hal ini bertujuan agar diketahui berapa persen (\%) rendemen yang didapat hingga proses menjadi abon.

\section{Pengemasan}

Abon yang telah dipres, didinginkan kemudian langsung dikemas di dalam kemasan yang tertutup rapat. Pengemasan harus sesegera mungkin dilakukan, untuk menghindari kontaminasi dan oksidasi dari kandungan minyak yang tersisa di dalam abon, karena reaksi oksidasi akan menimbulkan bau yang tengik. Jenis kemasan yang digunakan adalah jenis Low density polyethlene (LDPE).

\section{Mutu Produk}

\section{Uji ALT (Angka Lempeng Total) bahan baku}

Hasil uji (Pengujian II) ALT untuk bahan baku ikan lele dumbo dapat dilihat pada Tabel 1 .

Tabel 1. Hasil uji (Pengujian II) ALT Bahan Baku Ikan Lele Dumbo

\begin{tabular}{|c|c|c|c|c|}
\hline \multicolumn{3}{|c|}{ Ukuran (size) } & \multirow{2}{*}{ Satuan } & \multirow{2}{*}{$\begin{array}{c}\text { SNI } \\
\text { ALT } \\
(01- \\
2332.3- \\
2006) \\
\text { Bahan } \\
\text { Baku }\end{array}$} \\
\hline 3 ekor/kg & 4 ekor/kg & 5 ekor $/ \mathrm{kg}$ & & \\
\hline $1,7 \times 10^{3}$ & $2,1 \times 10^{3}$ & $1,9 \times 10^{3}$ & Kol/gram & $5 \times 10^{5}$ \\
\hline
\end{tabular}

Dari perhitungan dipastikan bahwa bahan baku lele masih memenuhi standar persyaratan bahan baku dalam proses pengolahan karena keseluruhan hasil pengujian ALT $<5 \times 10^{5}$. Hal ini disebabkan karena ikan yang digunakan adalah ikan hidup dan kondisi ikan masih dalam keadaan prima (kondisi ikan yang baru saja mati) sehingga sumber bakteri yang berasal dari isi perut , insang dan kulit belum mengontaminasi daging ikan.

\section{Uji ALT (Angka Lempeng Total) Abon} Ikan Lele Dumbo

Hasil Uji ALT (Pengujian II) abon dapat dilihat pada Tabel 2 .
Tabel 2. Hasil uji ALT (Pengujian II) Abon Ikan Lele Dumbo

\begin{tabular}{|c|c|c|l|c|}
\hline \multicolumn{3}{|c|}{ Ukuran (size) } & \multirow{2}{*}{ SNI ALT } \\
\cline { 1 - 3 } 3 ekor/kg & 4 ekor/kg & 5 ekor/kg & Satuan & $\begin{array}{c}(7690.1: 2 \\
013) \\
\text { Abon }\end{array}$ \\
\hline $2,5 \times 10^{3}$ & $2,5 \times 10^{3}$ & $2,3 \times 10^{3}$ & $\mathrm{Kol}^{/ \text {ram }}$ & $5,0 \times 10^{4}$ \\
\hline
\end{tabular}

Dari hasil uji ALT bahwa abon lele memenuhi standar persyaratan abon karena keseluruhan hasil pengujian ALT $<5 \times 10^{4}$. Hasil ini disebabkan karena diterapkannya proses sanitasi dan higienis pada saat proses pengolahan abon lele berlangsung seperti air yang yang digunakan, peralatan yang digunakan dan pengolah yang melakukan proses pengolahan serta dari bahan baku yang dalam keadaan hidup sehingga sangat menentukan mutu abon yang dihasilkan.

\section{Uji Eschericia Coli}

Hasil dari Pengujian E. coli lele ukuran (size) 3 ekor $/ \mathrm{kg}, 4$ ekor $/ \mathrm{kg}$, dan 5 ekor/kg yang dilakukan sebanyak 3 kali ulangan pada masing - masing size, diperoleh hasil < 3 APM . Pengujian E.coli yang dilakukan untuk abon lele dumbo dengan tujuan mengetahui apakah abon tersebut layak atau tidak untuk dikonsumsi. Karena, lele dumbo merupakan ikan yang dapat hidup diperairan kotor. $E$.coli merupakan flora normal didalam saluran pencernaan hewan dan manusia yang mudah mencemari air.

\section{Uji Kimia (air dan protein)}

Pengujian kimia meliputi uji kadar air dan kadar protein pada masing masing ukuran (size) yang dilakukan sebanyak 3 kali. Hasil perhitungan rata rata uji kimia dapat dilihat pada Tabel 3.

Tabel 3. Hasil Perhitungan Rata - rata

Uji Kimia (air dan protein) Abon Ikan Lele Dumbo

\begin{tabular}{|l|l|l|l|l|}
\hline \multirow{2}{*}{$\begin{array}{c}\text { Jenis } \\
\text { Pengujian }\end{array}$} & \multicolumn{3}{|c|}{ Ukuran (size) } & \multirow{2}{*}{$\begin{array}{c}\text { SNI } \\
\text { SN }\end{array}$} \\
\cline { 2 - 4 } & \multicolumn{1}{|c|}{ A } & \multicolumn{1}{|c|}{ B } & \multicolumn{1}{c|}{ C $1: 2013$} \\
\hline Air & $\begin{array}{l}4,34 \\
\%\end{array}$ & $\begin{array}{l}2,73 \\
\%\end{array}$ & $\begin{array}{l}5,42 \\
\%\end{array}$ & Maks 15 \% \\
\hline Protein & $\begin{array}{l}30,93 \\
\%\end{array}$ & $\begin{array}{l}30,19 \\
\%\end{array}$ & $\begin{array}{l}29,12 \\
\%\end{array}$ & Min 30 \% \\
& $\%$ & & \\
\hline
\end{tabular}

Keterangan : 
$\begin{array}{ll}\text { A } & \text { : Ukuran (size) } 3 \text { ekor } / \mathrm{kg} \\ \text { B } & \text { : Ukuran (size) } 4 \text { ekor } / \mathrm{kg} \\ \text { C } & \text { : Ukuran (size) } 5 \text { ekor } / \mathrm{kg}\end{array}$

Kadar Air

Berdasarkan Tabel 3, dapat dilihat bahwa kadar air abon ikan lele ukuran (size) A sebesar 4,34 \%, B sebesar 2,73\%, dan C sebesar 5,42\%. Rendahnya kadar air pada abon ini disebabkan adanya pemanasan dengan suhu tinggi yang menyebabkan menurunnya daya ikat air. Selama pemasakan (penggorengan) produk menerima panas sehingga kandungan air dalam bahan menguap yang ditandai dengan timbulnya gelembung selama proses penggorengan. Menurut Hadiwiyoto (1993), suhu tinggi dapat menyebabkan berbagai perubahan pada daging ikan, seperti: kadar airnya akan menurun disebabkan sebagian air yang ada akan menguap. Pada kadar air yang rendah, Aw menjadi rendah (Fardiaz, 1992)

\section{Kadar Protein}

Berdasarkan Tabel 3, dapat dilihat bahwa jumlah protein abon ikan lele Ukuran (size) A sebesar 30,93\%, B sebesar 30,19\%, C sebesar 29,12\%. Tingginya kadar protein yang dimiliki abon lele ini disebabkan pada bahan baku ikan lele sebesar 18,70 \% (Forrest et all; 1992 dalam Murniyati dkk, (2011). Hal lainnya yang mempengaruhi dari terjadinya kenaikan kadar protein adalah karena kadar air menjadi berkurang sehingga persentase (\%) protein menjadi meningkat serta dari bawang merah dan bawang putih dan juga bumbu - bumbu yang lainnya, sehingga mempengaruhi kadar protein pada abon.

\section{Rendemen}

Dari semua hasil rendemen berupa data yang didapatkan kemudian di masukkan kedalam rancangan percobaan dengan menggunakan
Rancangan Acak Lengkap faktorial (RAL).

\section{Pengaruh berat ikan lele dumbo (Clarias gariepinus) terhadap rendemen abon ikan lele dumbo}

Rancangan percobaan yang digunakan adalah Rancangan Acak Lengkap karena hanya ada satu faktor pembeda pada percobaan yang dilakukan (Hanafiah, 1991). Faktor pembeda yang dimaksud adalah :

Ikan lele dumbo dengan jumlah 3 ekor/kg (A)

Ikan lele dumbo dengan jumlah 4 ekor/kg (B)

Ikan lele dumbo dengan jumlah 5 ekor/kg (C)

Pengulangan dilakukan 3 kali di masing - masing ukuran (size) hasil perhitungan pengamatan I, II dan III , kemudian diperoleh perhitungan rendemen dengan 9 (sembilan) data dari rata - rata perhitungan rendemen, lalu data hasil percobaan tersebut ditata dalam tabel analisis data yang dapat dilihat pada Tabel 4.

Tabel 4. Data Rata - Rata Perhitungan Rendemen

\begin{tabular}{|c|c|c|c|}
\hline \multirow{2}{*}{ Ulangan } & \multicolumn{3}{|c|}{ Ukuran (size) } \\
\cline { 2 - 4 } & $\mathrm{A}$ & $\mathrm{B}$ & $\mathrm{C}$ \\
\hline 1 & $25,52 \%$ & $27,54 \%$ & $28,91 \%$ \\
\hline 2 & $26,07 \%$ & $27,61 \%$ & $28,63 \%$ \\
\hline 3 & $26,17 \%$ & $27,45 \%$ & $29,12 \%$ \\
\hline Total & $77,67 \%$ & $82,6 \%$ & $86,66 \%$ \\
\hline Rata-rata & $25,92 \%$ & $27,53 \%$ & $28,88 \%$ \\
\hline
\end{tabular}

Dari hasil rata - rata perhitungan rendemen yang disajikan pada Tabel 4 , dapat dilihat bahwa pada lele ukuran (size) $\mathrm{C}$ rendemen yang didapat lebih besar yaitu 28,88\% hal ini dikarenakan pada ukuran (size) $\mathrm{C}$ tersebut ikan lele tidak memiliki lemak yang banyak dan telur sehingga rendemen yang didapat lebih besar, hal lainnya yang mempengaruhi rendemen yang didapat adalah ukuran besar kepala ikan yang dimiliki pada ukuran (size) $\mathrm{C}$ lebih kecil dibandingkan ukuran (size) A dan B.

Pada hasil penelitian perhitungan rendemen A sebesar 25,92\% dan B 
sebesar 27,53\%, hal ini dikarenakan pada ukuran (size) A dan B ikan lele memiliki telur dan lemak didalam isi perut nya, sehingga rendemen yang didapat lebih kecil terlebih lagi pada ukuran (size) A kepala dan tulang ikan memiliki ukuran yang lebih besar serta kulit yang lebih tebal juga lemak yang lebih banyak sehingga sangat mempengaruhi hasil dari rendemen yang didapat. Menurut Anonymous (2007), salah satu hal yang mempengaruhi rendemen adalah kondisi biologis bahan baku pada saat ditangkap akan berpengaruh terhadap persentase atau berat rendemen.

Hasil perhitungan (Rancangan Acak Lengkap) dan Tabel Anova didapat lah hasil bahwa $\mathrm{F}_{\text {hitung }}>\mathrm{F}_{\text {tabel, }}$ hal ini berarti ada pengaruh yang signifikan antara berat lele dumbo (Clarias gariepinus) terhadap rendemen abon ikan lele dumbo.

\section{Penentuan Masa Umur Simpan}

Penentuan masa umur simpan dan masa kedaluwarsa dilakukan metode Arrhenius, Hasil percobaan (Trial and eror) uji TBA dapat dilihat pada Tabel 5 .

Tabel 5. Hasil Uji TBA (Trial and eror)

\begin{tabular}{|c|c|c|c|c|}
\hline \multicolumn{5}{|c|}{ Suhu $27^{\circ} \mathrm{C}$} \\
\hline \multirow{2}{*}{ Hari } & \multirow{2}{*}{ Berat Sempel } & \multicolumn{2}{|c|}{ Optical Density (OD/gr sampel x 100\%) } & \multirow{2}{*}{ Rata - rata } \\
\cline { 3 - 4 } & & $\mathrm{A}$ & $\mathrm{B}$ & 0,0065 \\
\hline $0^{*}$ & 5,0421 & 0,004 & 0,005 & 0,0215 \\
\hline 1 & 5,0412 & 0,014 & 0,015 & 0,0455 \\
\hline $2^{*}$ & 5,0431 & 0,031 & 0,029 & 0,0505 \\
\hline 3 & 5,0444 & 0,033 & 0,035 & 0,2365 \\
\hline $4^{*}$ & 5,0472 & 0,157 & 0,159 & 0,2510 \\
\hline 5 & 5,0446 & 0,169 & 0,164 & 0,3210 \\
\hline $6^{*}$ & 5,0410 & 0,214 & 0,214 & 0,3250 \\
\hline 7 & 5,0436 & 0,217 & 0,216 & 1,6980 \\
\hline $8^{*}$ & 5,0428 & 1,130 & 1,132 & 1,6970 \\
\hline 9 & 5,0432 & 1,131 & 1,132 & 1,7045 \\
\hline $10^{*}$ & 5,0473 & 1,136 & 1,137 & \\
\hline
\end{tabular}

Hasil yang didapatkan dari uji TBA dengan (trial and eror) digambar dalam bentuk regresi. Gambar grafik dapat dilihat pada Gambar 4.

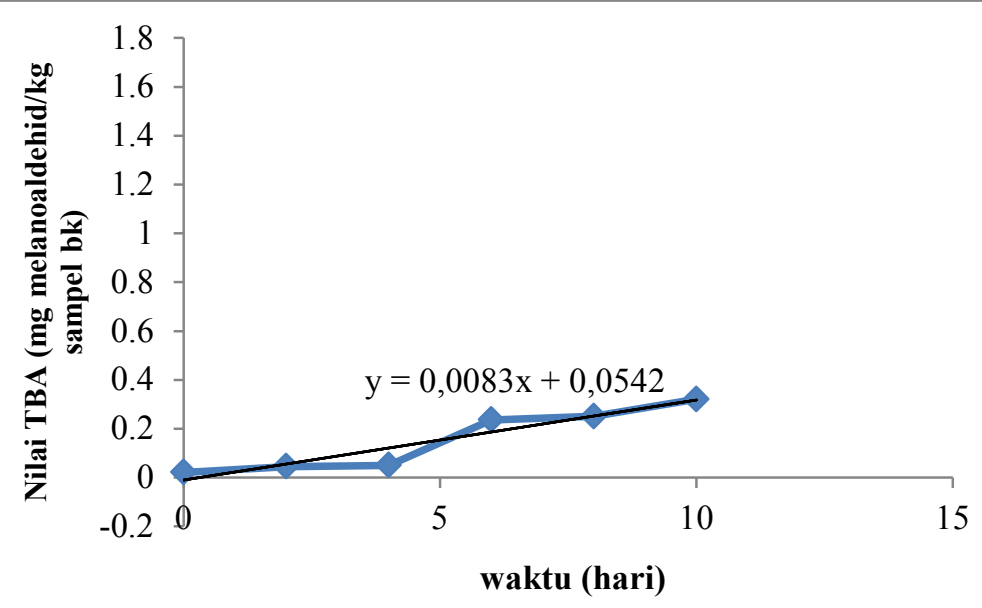

Gambar 4. Grafik nilai TBA (trial and eror). 
Hasil uji regresi pada uji TBA (trial and eror) pada suhu $27^{\circ} \mathrm{C}$ (suhu ruang) menunjukkan hasil linier dengan persamaan $y=0,0083 x+0,0542$ ini berarti bahwa setiap 2 (dua) hari sekali terjadi perubahan nilai TBA sebesar 0,0083/hari ini disebabkan karena terjadi oksidasi pada abon yang yang disimpan pada suhu ruang $\left(27^{\circ} \mathrm{C}\right)$. Suhu dan kelembaban juga mencerminkan suatu indeks kerusakan (deterioration index) yang dikenal DI, seperti dikemukakan oleh Brooks (Mackay dan Jamieson, 1970). Hal ini menunjukkan bahwa terjadi perubahan penurunan mutu TBA pada abon lele yaitu hasil uji TBA yang dapat dilihat pada (Tabel 5). Hal ini disebabkan kandungan minyak yang terdapat dalam abon teroksidasi menghasilkan radikal bebas. Dengan adanya oksigen pada suhu ruang, asam lemak tak jenuh bereaksi menghasilkan hidrogen peroksida dan radikal bebas (Winarno, 1987). Perlakuan ini dilakukan terhadap 3 kelompok abon yang diteliti, pada hari penyimpanan terakhir (hari-10) produk dinyatakan tidak layak untuk dikonsumsi.

Penelitian TBA yang kedua dilakukan pada suhu $25^{\circ} \mathrm{C}$ yang disimpan di dalam chilling yang dilengkapi dengan thermostat , kemudian di suhu $35^{\circ} \mathrm{C}$ yang disimpan di dalam inkubator, lalu pada suhu $45^{\circ} \mathrm{C}$ yang disimpan pada oven. Hasil uji TBA (Thiobarbituric acid) untuk masing masing ukuran (size) pada suhu $25^{\circ} \mathrm{C}$, $35^{\circ} \mathrm{C}$, dan $45^{\circ} \mathrm{C}$ dapat dilihat pada Tabel 5 .

Hasil uji pada suhu $35^{\circ} \mathrm{C}$ menunjukkan, bahwa pada tiga perlakuan ukuran yang berbeda terjadi perubahan organoleptik pada parameter Bau. pada abon ikan ukuran 3 ekor $/ \mathrm{kg}$. Perubahan bau pada hari ke 8 TBA 0.2055 , pada ukuran 4 ekor $/ \mathrm{kg}$ penurunan bau pada hari ke 8 nilai TBA 0.203 sedangkan pada ukuran 5 ekor $/ \mathrm{kg}$ nilai TBA pada hari ke 8 sebesar 0.2054 ini menunjukkan bahwa perlakuan suhu tidak mempengaruhi peningkatan TBA pada suhu yang sama.

Hasil uji ikan dari 3(tiga) perlakuan pada suhu yang berbeda (Tabel 5) menunjukkan bahwa, pada suhu $25^{\circ} \mathrm{C}$ pada semua ukuran ikan, hasil uji TBA abon terjadi perubahan peningkatan TBA yang terjadi pada hari ke 6 (enam) sedangkan pada suhu $35^{\circ} \mathrm{C}$ dan $45^{\circ} \mathrm{C}$ perubahan terjadi pada hari ke 8 (delapan) ini menunjukkan bahwa semakin meningkat suhu penyimpanan semakin lambat terjadi peningkatan TBA, hal ini kemungkinan disebabkan $R H$ (kelembaban) ruangan rendah pada suhu $25^{\circ} \mathrm{C}$, karena sampel yang diletakkan didalam chilling, yang berakibat kelembaban udara sekitar pada suhu tersebut lembab, dan reaksi oksidasi berjalan cepat (Murniyati $d k k$, 2011).

\section{Uji TBA dan Organoleptik Parameter Bau}

Hasil uji organoleptik dengan Parameter Bau, sebagai pembanding hasil uji TBA untuk mendapatkan banyak nya hari penguujian pada masing - masing ukuran (size) di suhu $25^{\circ} \mathrm{C}$, $35^{\circ} \mathrm{C}$, dan $45^{\circ} \mathrm{C}$ dapat dilihat pada Tabel 6,7 , dan 8 . 
Tabel 6. Hasil Uji Organoleptik Parameter Bau Ukuran (size) 3 ekor/kg

\begin{tabular}{|c|c|c|c|}
\hline \multirow{2}{*}{$\begin{array}{c}\text { Penyimpanan } \\
\text { (hari) }\end{array}$} & \multicolumn{2}{|c|}{ Tanggapan } & \multirow{2}{*}{$\begin{array}{c}\text { Angka TBA (mg } \\
\text { malonadehid/kg sampel) }\end{array}$} \\
\cline { 2 - 3 } & Benar & Salah & 0,0055 \\
\hline 0 & 15 & 15 & 0,0885 \\
\hline 2 & 16 & 14 & 0,1015 \\
\hline 4 & 17 & 13 & 0,1122 \\
\hline 6 & 18 & 12 & 0,2055 \\
\hline $8 *$ & 19 & 11 & 0,2095 \\
\hline 10 & 22 & 8 & \\
\hline
\end{tabular}

Tabel 7. Hasil Uji Organoleptik Parameter Bau Ukuran (size) 4 ekor/kg

\begin{tabular}{|c|c|c|c|}
\hline \multirow{2}{*}{$\begin{array}{l}\text { Penyimpanan } \\
\text { (hari) }\end{array}$} & \multicolumn{2}{|c|}{ Tanggapan } & \multirow{2}{*}{$\begin{array}{l}\text { Angka TBA (mg malonadehid/kg } \\
\text { sampel) }\end{array}$} \\
\hline & Benar & Salah & \\
\hline 0 & 17 & 13 & 0,0198 \\
\hline 2 & 16 & 14 & 0,0456 \\
\hline 4 & 15 & 15 & 0,0899 \\
\hline 6 & 15 & 15 & 0,1355 \\
\hline $8 *$ & 19 & 11 & 0,2034 \\
\hline 10 & 21 & 9 & 0,3311 \\
\hline
\end{tabular}

Tabel 8. Hasil Uji Organoleptik Parameter Bau Ukuran (size) 5 ekor/kg

\begin{tabular}{|c|c|c|c|}
\hline \multirow{2}{*}{$\begin{array}{c}\text { Penyimpanan } \\
\text { (hari) }\end{array}$} & \multicolumn{2}{|c|}{ Tanggapan } & $\begin{array}{c}\text { Angka TBA (mg malonadehid/kg } \\
\text { sampel) }\end{array}$ \\
\cline { 2 - 3 } & Benar & Salah & 0,0055 \\
\hline 0 & 17 & 13 & 0,0885 \\
\hline 2 & 16 & 14 & 0,1015 \\
\hline 4 & 15 & 15 & 0,1122 \\
\hline 6 & 17 & 13 & 0,2054 \\
\hline $8 *$ & 19 & 11 & 0,2095 \\
\hline 10 & 20 & 10 & \\
\hline
\end{tabular}

Hasil pengujian organoleptik untuk masing - masing ukuran (size) didapatkan hasil bahwa ukuran 3 ekor/kg dengan nilai TBA 0,2055 A pada hari ke-8 telah mengalami ketengikan hal ini diperkuat dengan hasil uji organoleptik dengan parameter bau oleh 30 orang panelis tabel $\alpha 0,1 \%$ adalah 19, didapat kan hasil bahwa sebanyak 19 orang panelis dibawah rata - rata $(<7)$, yang berarti menyatakan benar pada hari ke- 8 hasil uji TBA dengan nilai 0,2055 A pada ukuran 3 ekor/kg sudah dikatakan tengik. Untuk ukuran $1 \mathrm{~kg} 4$ pada hari ke-8 nilai TBA 0,203 A dan 19 orang panelis juga bertanggapan benar, kemudian ukuran 1 kg 5 juga pada hari ke-8 sudah mengalami ketengikan hasil uji TBA adalah 0,2054 dan 19 orang menyatakan benar dengan hasil rata - rata $(<7)$ sebanyak 19 orang. Dari ke tiga hasil yang didapat diketahui bahwa ukuran (size) tidak mempengaruhi umur simpan meskipun hasil uji TBA yang didapat berbeda, akan tetapi dari hasil uji organoleptik parameter bau pada hari ke-6 memiliki perbedaan hasil pada ukuran 3 ekor/ kg hasil uji organoleptik parameter bau 17 orang panelis $(<7)$, ukuran 4 ekor $/ \mathrm{kg}$ jumlah panelis 15 orang yang bertanggapan benar $(<7)$, 
dan ukuran 5 ekor/kg jumlah panelis 17

orang yang bertanggapan benar $(<7)$.

Tabel 9. Hasil Uji TBA Masing - Masing Ukuran (size) Pada Suhu $25^{\circ} \mathrm{C}, 35^{\circ} \mathrm{C}$ dan

\begin{tabular}{|c|c|c|c|c|c|c|c|c|c|}
\hline \multirow{3}{*}{ Hari } & \multicolumn{9}{|c|}{ Ukuran (size) } \\
\hline & \multicolumn{3}{|c|}{3 ekor $/ \mathrm{kg}$} & \multicolumn{3}{|c|}{4 ekor/kg } & \multicolumn{3}{|c|}{5 ekor $/ \mathrm{kg}$} \\
\hline & $25^{\circ} \mathrm{C}$ & $35^{\circ} \mathrm{C}$ & $45^{\circ} \mathrm{C}$ & $25^{\circ} \mathrm{C}$ & $35^{\circ} \mathrm{C}$ & $45^{\circ} \mathrm{C}$ & $25^{\circ} \mathrm{C}$ & $35^{\circ} \mathrm{C}$ & $45^{\circ} \mathrm{C}$ \\
\hline 0 & 0,0055 & 0,0054 & 0,0053 & 0,0201 & 0,0199 & 0,0188 & 0,0111 & 0,0111 & 0,0088 \\
\hline 2 & 0,0295 & 0,0885 & 0,0411 & 0,0402 & 0,0455 & 0,0233 & 0,0441 & 0,0533 & 0,0111 \\
\hline 4 & 0,1575 & 0,1015 & 0,1095 & 0,1355 & 0,0899 & 0,1241 & 0,1011 & 0,1061 & 0,0812 \\
\hline 6 & $0,2145^{*}$ & 0,1122 & 0,1565 & $0,2977^{*}$ & 0,1355 & 0,1590 & $0,1199 *$ & 0,1262 & 0,1733 \\
\hline 8 & 0,6311 & $0,2055^{*}$ & $0,2705^{*}$ & 1,2633 & $0,2033^{*}$ & $0,2211^{*}$ & 1,2643 & $0,1830^{*}$ & $0,2521^{*}$ \\
\hline 10 & 1,1365 & 0,2095 & 0,6355 & 1,3777 & 0,3311 & 0,0188 & 1,3566 & 0,3277 & 0,6299 \\
\hline
\end{tabular}

Hasil yang didapatkan dari pengujian TBA pada ukuran (size) 3 ekor $/ \mathrm{kg}, 4$ ekor $/ \mathrm{kg}$, dan 5 ekor $/ \mathrm{kg}$ pada suhu $25^{\circ} \mathrm{C}$ telah mengalami ketengikan pada hari ke-6 (enam) sedangkan pada suhu $35^{\circ} \mathrm{C}$ serta $45^{\circ} \mathrm{C}$ pada hari ke- 8 $\mathrm{kg}$ :

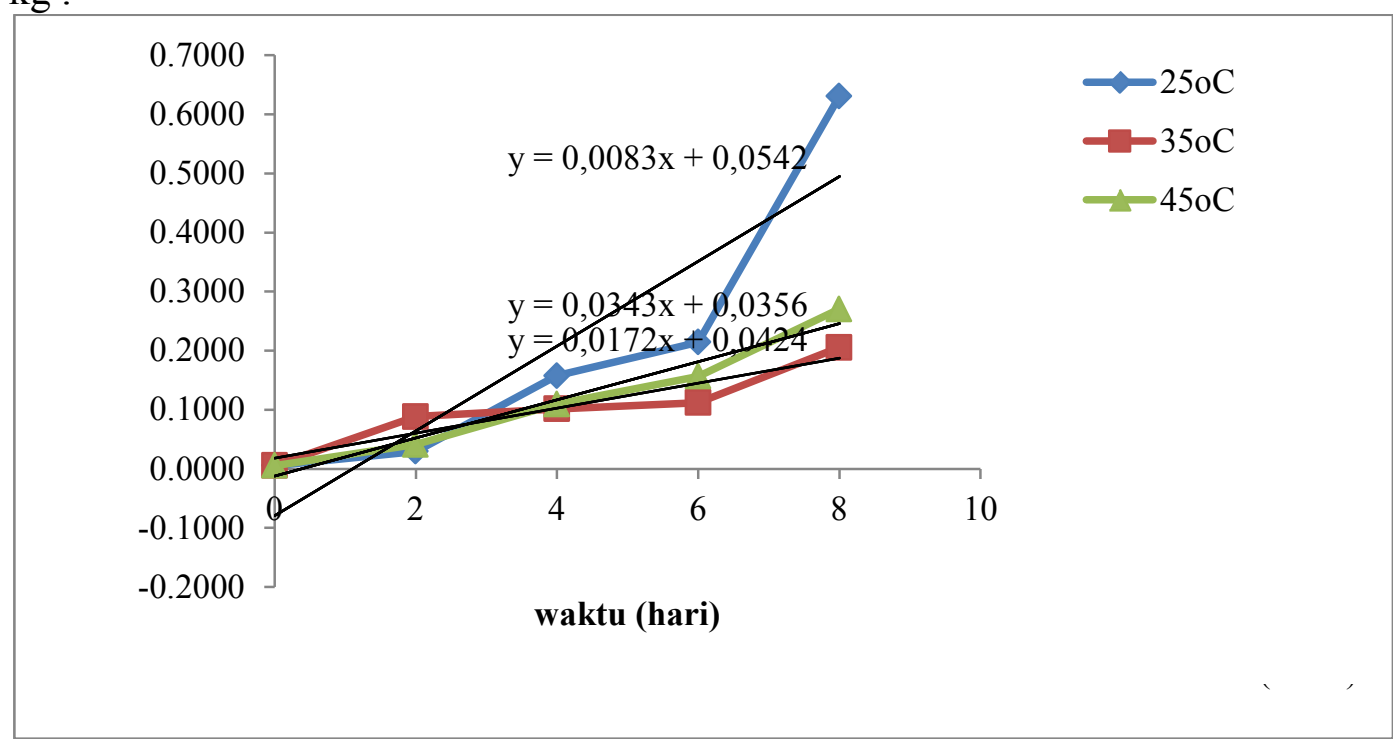

(delapan) mengalami ketengikan, sehingga salah satu dari hasil uji TBA salah satu ukuran (size) yaitu 3 ekor $/ \mathrm{kg}$ dilanjutkan dalam bentuk regresi. Gambar 5 merupakan bentuk persamaan regresi ukuran (size) 3 ekor/

Gambar 5. Grafik hubungan antara waktu penyimpanan dengan nilai TBA pada beberapa suhu penyimpanan 
Laju kemunduran mutu adalah uji untuk mengetahui seberapa jauh penurunan mutu yang terjadi, pada masing masing perlakuan dalam hal ini adalah suhu. Hasil uji laju penurunan mutu pada masing masing perlakuan menunjukkan nilai regresi pada suhu masing masing dapat dilihat pada Tabel 10.

Tabel 10. Tabel Persamaan Regresi untuk menentukan nilai $\mathrm{K}$

\begin{tabular}{|l|lr|l|}
\hline Suhu & $\begin{array}{l}\text { Persamaan } \\
\text { regresi }\end{array}$ & Nilai $\mathrm{K}$ \\
\hline $25^{\circ} \mathrm{C}$ & $\begin{array}{l}\mathrm{Y}=0,0083 \mathrm{x} \\
0,0542\end{array}$ & 0,0834 \\
\hline $35^{\circ} \mathrm{C}$ & $\begin{array}{l}\mathrm{Y}=0,0343 \mathrm{x} \\
0,0356\end{array}$ & 0,0343 \\
\hline $45^{\circ} \mathrm{C}$ & $\begin{array}{l}\mathrm{Y}=0,0172 \mathrm{x} \\
0,0424\end{array}$ & 0,0172 \\
\hline
\end{tabular}

Selanjutnya apabila nilai - nilai K ini diterapkan dalam rumus Arrhenius, yaitu $\mathrm{K}=$ Ko.e-E/RT atau Ln K = Ln Ko -E/RT, karena Lnko dan -E/RT adalah konstanta, maka persamaan tersebut dapat dituliskan sebagai Ln $\mathrm{K}=$ $\mathrm{A}+\mathrm{B} .1 / \mathrm{T}$, sehingga apabila setiap nilai $\mathrm{K}$ dan $1 / \mathrm{T}$ diplotkan dalam sebuah grafik, maka akan diperoleh grafik seperti pada Gambar 8. Di peroleh persamaan regresi linier yaitu $\mathrm{y}=6718,1 \mathrm{x}-25,90$. Persamaan tersebut untuk menentukan kinetika perubahan angka TBA abon lele selama penyimpanan sebagai fungsi suhu. Energi aktivasi dihitung dari perkalian antara nilai kemiringan kurva (slope) dengan R. Nilai kemiringan kurva dari persamaan garis ini sebesar 6718,1 merupakan nilai $\mathrm{E} / \mathrm{R}$ dari persamaan Arrhenius sedangkan $\mathrm{R}$ (konstanta gas) sebesar 1,986 $\mathrm{kal} / \mathrm{mol}^{0} \mathrm{~K}$.

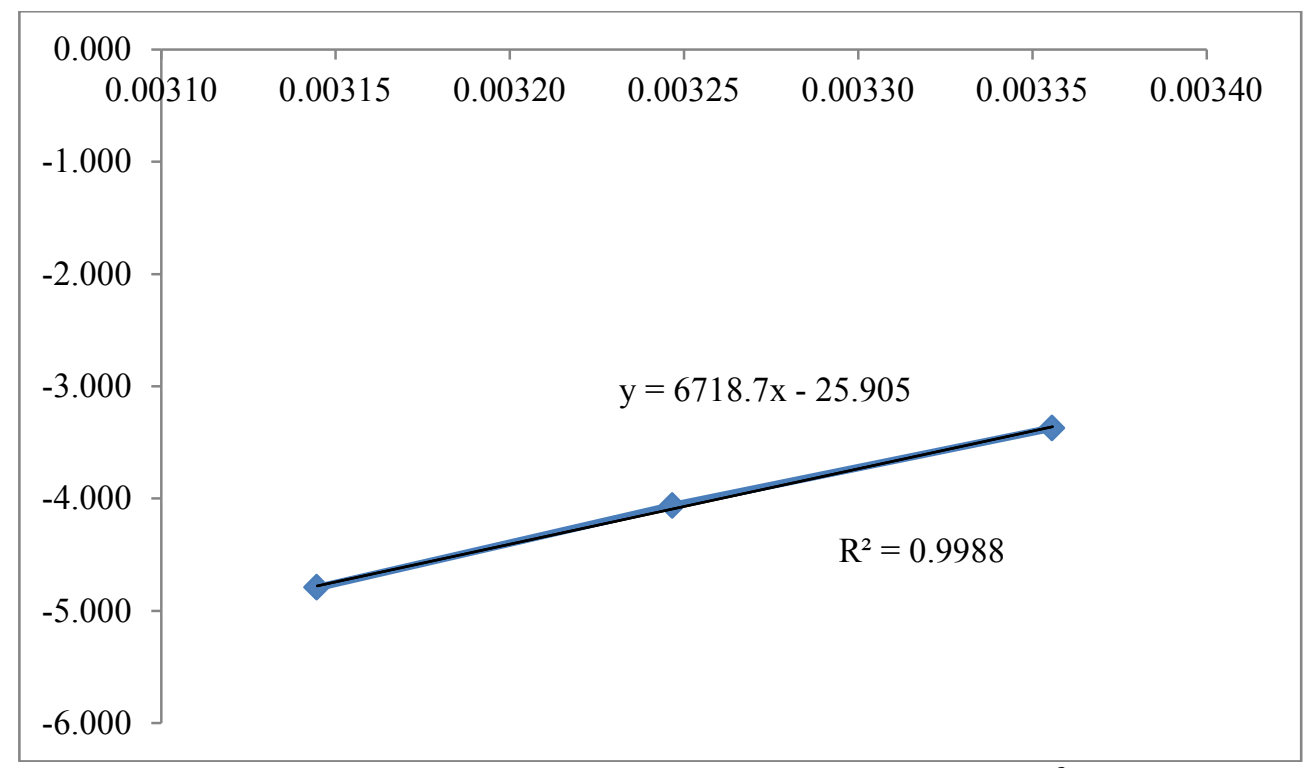

Gambar 6. Grafik hubungan antara suhu penyimpanan $\left(1 / \mathrm{T}^{\circ} \mathrm{K}\right)$ dengan lnk.

Nilai Q10 dapat dihitung dengan membagi laju penurunan mutu pada suhu +10 dengan suhu tertentu. Nilai Q10 Abon lele pada penyimpanan suhu $25{ }^{\circ} \mathrm{C}$ dan $35^{\circ} \mathrm{C}$ adalah 0,0967 sedangkan nilai Q10 untuk suhu 35 dan $45^{\circ} \mathrm{C}$ sebesar 0,0876 . Nilai Q10 rata rata 0,09215. Nilai Q10 tersebut dapat digunakan untuk menentukan umur simpan seperti terlihat pada Tabel 11.

Tabel 11. Laju ketengikan dan penentuan nilai Q10

\begin{tabular}{|l|l|l|}
\hline Suhu ${ }^{\circ} \mathrm{K}$ & Laju ketengikan & $\mathrm{Q} 10$ \\
\hline 298 & $6,36 \times 10^{-9} /$ hari & 0,0921 \\
\hline 308 & $2,74 \times 10^{-8} /$ hari & 0,0967 \\
\hline 318 & $2,55 \times 10^{-8} /$ hari & 0,0876 \\
\hline
\end{tabular}


Penentuan umur simpan dapat ditentukan dengan rumus $\mathrm{Ts}=$ $\mathrm{Ts}_{1} . \mathrm{Q} 10^{\mathrm{dT} / 10}$, maka rumus umur simpan abon ikan lele dumbo menjadi Ts $=8 \mathrm{x}$ $0,0921^{\mathrm{dT} / 10}$. Dengan persamaan tersebut, maka dapat ditentukan umur simpan abon ikan lele dalam berbagai suhu. Jika abon ikan lele disimpan pada suhu chilling $5^{\circ} \mathrm{C}$, maka umur simpan abon ikan lele menjadi 28,2 bulan pada suhu $5^{\circ} \mathrm{C}$ atau dari tanggal 30 April $2013 \mathrm{~s} / \mathrm{d}$ 2 september 2015 sehingga masa kedaluwarsa nya adalah 2 September 2015.

\section{KESIMPULAN DAN SARAN Kesimpulan}

1. Perhitungan rendemen rata - rata ukuran (size) 3 ekor $/ \mathrm{kg}$ sebesar $25,92 \%$, ukuran (size) 4 ekor/kg sebesar 27,53\%, dan ukuran (size) 5 ekor $/ \mathrm{kg}$ sebesar $28,88 \%$.

2. Pengujian mutu bahan baku ikan lele dumbo yaitu uji ALT dengan hasil uji untuk lele ukuran (size) 3 ekor/kg yaitu $1,7 \times 10^{3}$, ukuran (size) 4 ekor $/ \mathrm{kg}$ yaitu $2,1 \times 10^{3}$, dan ukuran (size) 5 ekor $/ \mathrm{kg}$ yaitu $1,9 \times 10^{3}$. Pengujian mutu abon lele dumbo uji ALT ukuran (size) 3 ekor/kg yaitu 2,5 $\mathrm{x} 10^{3}, 4$ ekor $/ \mathrm{kg}$ yaitu $2,5 \times 10^{3}$ dan 5 ekor $/ \mathrm{kg}$ yaitu $2,3 \times 10^{3}$. Dan hasil uji E. Coli abon ikan lele untuk ukuran (size) 3 ekor $/ \mathrm{kg}, 4$ ekor $/ \mathrm{kg}$, dan 5 ekor $/ \mathrm{kg}$ adalah $<3$ APM. Pengujian kimia rata - rata (air, dan protein) abon ukuran (size) 3 ekor $/ \mathrm{kg}$ uji air sebesar 4,34\%, 4 ekor $/ \mathrm{kg}$

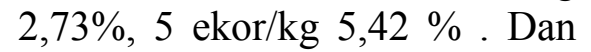
pada uji protein ukuran 3 ekor/kg 30,93 \%., ukuran 4 ekor $/ \mathrm{kg}$ $30,19 \%$, dan ukuran 5 ekor/kg $29,12 \%$. Pengujian TBA untuk ukuran (size) 3 ekor $/ \mathrm{kg}, 4$ ekor/kg dan 5 ekor/kg disuhu $25^{\circ} \mathrm{C}$ telah mengalami kenaikan TBA yang tinggi pada hari ke- 6 sedangkan pada suhu $35^{\circ} \mathrm{C}$ dan $45^{\circ} \mathrm{C}$ kenaikan TBA yang tinggi terjadi pada hari ke-8.

3. Perhitungan untuk umur simpan yang dilakukan pada ukuran (size) 3 ekor/kg didapatkan hasil bahwa umur simpan abon lele selama 28,2 bulan suhu $5^{0} \mathrm{C}$ atau dari tanggal 16 September 2013 s/d 16 Maret 2016 sehingga masa kedaluwarsa nya adalah 16 Maret 2016.

Saran

1. Untuk perhitungan ren pada pengolahan abon seb;

lele yang digunakan sebagai bahan baku adalah 5 ekor $/ \mathrm{kg}$ dan ukuran (size) permintaan pasar yaitu $8 \mathrm{~s} / \mathrm{d} 10 \mathrm{ekor} / \mathrm{kg}$.

2. Untuk penentuan masa umur simpan dan masa kedaluwarsa sebaiknya digunakan dengan parameter uji yang lainnya sebagai pendukung.

\section{DAFTAR PUSTAKA}

Badan Standar Nasional (BSN). 2006. Standar Nasional Indonesia (SNI 01-2792.2-2006), tentang Persyaratan Bahan Baku. DSN. Jakarta.

2006. Standar Nasional Indonesia (SNI 01-2332.32006), tentang Cara Uji Mikrobiologi- Bagian 3: Penentuan Angka Lempeng Total (ALT) Pada Produk Perikanan. BSN. Jakarta.

$\begin{array}{cr}\text { Indonesia } & \text { Nasional } \\ \text { Penentuan Kadar } & \text { Tir. (SNI- } \\ 01-2354.3-2006) . & \text { BSN. } \\ \text { Jakarta } & \\ \text { Indonesia } & \text { Tentang } \\ \text { Penentuan Kadar } & \text { Protein. } \\ \text { (SNI-01-2354.4-2006). } \\ \text { BSN. Jakarta } \\ \text {----.2006. Standar } & \text { Nasional } \\ \text { Indonesia } & \text { Tentang } \\ \text { Persyaratan air } & \text { industri }\end{array}$


pengolahan, (SNI 013553:2006). BSN. Jakarta.

2013. Standar Nasional Indonesia Tentang Abon Ikan- Bagian 1: Spesifikasi. (SNI- 7690.1:2013). BSN. Jakarta.

Standar Nasional
Indonesia Tentang Abon
Ikan- Bagian 2 :
Persyaratan Bahan Baku.
(SNI- 7690.2:2013). BSN.
Jakarta.
Indonesia Tentang Abon
Ikan- Bagian 3 :
Penanganan
Pengolahan.
7690.3:2013). BSN. Jakarta.

Direktorat Jenderal Pengolahan dan Pemasaran Hasil Perikanan. 2011, Pusat Data Statistik dan Informasi. Kementerian Kelautan Dan Perikanan.

Desroiser, N.W. dan James N. Desroiser. 1997. The Technology of Food Preservation. AVI Pub Co, Westport, Connecticut.

Estiasih dan Ahmadi, KGS.2011. Teknologi Pengolahan Pangan. Bumi Aksara. Jakarta

Floros, J. D. And V. Gnanasekharan. 1993. Shelf life prediction of packaged foods: chemichal, biological, physical, and nutritional aspects. G. Chlaralambous (Ed).

Elsevier Publ.,London.

Jhon, M. deMAN. 1997. Kimia makanan. Koasih pandawinata, Bandung.

Kusnandar, Feri. 2004. Aplikasi program computer sebagai alat bantu penetuan umur simpan produk pangan: metode Arrhenius. Pelatihan Pendugaan Waktu Kedaluawarsa (Shelf Life)
Bahan dan Produk Pangan. Bogor, 1 - 2 Desember 2004. Pusat Studi Pangan dan Gizi, Institut Pertanian Bogor.

Murniyati, Theresia D. S, dan Ijah Muljanah. 2011. Pengolahan Filet dan Produk Olahan Berbasis Daging Lumat Lele. Balai Besar Penelitian Dan Pengembangan Pengolahan Produk Dan Bioteknologi Kelautan Dan Perikanan, Badan Penelitian dan Pengembangan Kelautan dan Perikanan Kementrian Kelautan dan Perikanan. Jakarta

M. Ghufan H, Kordi K. 2010, Budi daya ikan lele dikolam terpal. Edisi I, Yogyakarta.

Suryani, et al. 2008. Membuat Aneka Abon. Penebar Swadaya. Jakarta.

Wisnu Cahyadi. 2008. Analisis dan aspek kesehatan bahan tambahan pangan. Bumi Aksara. Jakarta.

Winarno. 2008. Kimia Pangan \& Gizi. MBRIO Press. Bogor. 